\title{
Parliament and Political Disengagement: Neither Waving nor Drowning
}

Political Quarterly (2007), vol.78, no.3, pp.364-373.

\author{
Dr Alexandra Kelso \\ Department of Politics and International Relations \\ School of Social Science \\ University of Southampton \\ SO17 1BJ
}

A.Kelso@soton.ac.uk

\begin{abstract}
$\underline{\text { Abstract }}$
Concern about political disengagement is prevalent in British politics, and this article seeks to examine what the Westminster parliament has been doing to address it. Recent reforms and recommendations from various parliamentary committees are examined, including increased use of the internet to disseminate information about parliament, the use of online consultation mechanisms, and the tentative extension of parliament's petitioning processes. The discussion is couched in the representative origins of parliament, its adaptation to democratic politics and the extent to which its response to political disengagement is contextualised by its representational, rather than its democratic, role. The article addresses whether parliament can approach these issues in a 'holistic' fashion, and as a 'unified' institution within the political system.
\end{abstract}

Key Words

Westminster parliament, political disengagement, representation, democracy 
Debating the problems facing mature liberal democracies as a result of declining voter turnout has become a well worn groove in contemporary politics. An academic literature has flourished around the reasons for this declining electoral participation, and around democratic remedies for it. After fifteen post-war general elections in which voter turnout averaged just over 76 percent, turnout at the 2001 UK general election dipped to 59.4 percent, triggering a tidal wave of public and academic discussion about what had caused the fall-off. The 12 point drop from the 1997 turnout figure prompted discussion about an 'apathetic landslide' in Britain. ${ }^{1}$ The situation was little improved in 2005, when turnout barely increased to just over 61 percent. Of particular concern to some commentators were the low electoral participation rates among those aged 18-24, with only 37 percent of that group participating in the 2005 election.

Fired by the electoral statistics, several UK think tanks and public bodies have produced additional evidence outlining the health, or apparent lack thereof, of democratic politics in Britain. The Audit of Political Engagement, conducted jointly by the Hansard Society and the Electoral Commission, found in 2006 that while 56 percent of those it surveyed reported an interest in politics, just 39 percent felt they were knowledgeable about politics. Only 33 percent of respondents agreed that by getting involved in politics, people could change the way the country was governed, and only 14 percent described themselves as political activists. These figures are complemented by the 2006 Eurobarometer survey, which not only continued to show declining trust in national institutions across the EU nations, but showed a particular fall in the UK. Just 24 percent of respondents said they tended to trust the government, down from 30 percent in 2005, with only 29 percent trusting parliament, down from 36 percent in the previous poll: both sets of figures placed the UK in the bottom ranks of the EU nations in terms of trust in national institutions.

What has occasionally been missing from analysis of the phenomenon of democratic disengagement, however, is detailed examination of what political institutions themselves are actually doing to address it. The fact remains that the UK parliament at Westminster has done much in recent years to engage the public with its work and activities. Parliament's growing orientation towards, and interest in, the issue of political engagement helps highlight the extent to which parliament is still continuing to adapt to the democratisation of the British state some 200 years after it was first begun. As an 
institution of representative democracy, parliament's response to the phenomenon of disengagement from traditional ways of 'doing' politics illustrates the tensions that exist between representation and democracy in contemporary Britain. This tension is exacerbated by a misunderstanding of the function of parliament as a link between government and governed, which is fuelled by a shifting debate between a focus on the quality of representative democracy in Britain and on the quality of participatory democracy.

\section{Parliament's Representative and Democratic Functions}

Parliaments have multiple roles, but their most basic function is that of linking government and governed. By providing a forum where the concerns of the electorate can be aired and (possibly) addressed, and where the actions of government can be explained and scrutinised, parliament facilitates the interest articulation and conflict resolution necessary for a healthy political system. The Westminster parliament's historical role as an institution of representation - whereby members of the political nation, however conceived, could access the executive through representational mechanisms and have their grievances addressed - has meant that it has been the only forum through which executive actions can be legitimated. ${ }^{2}$ Its ancient role as an institution of representation enables parliament to link government and governed together in the British political system.

Consequently, government in Britain has always been parliamentary government, understood to be government through parliament, not by it. Crucially, the historical development of the British state means that parliament was understood as an institution of representation long before the advent of democracy. Parliament adapted to the democratisation of the British state once that process had begun, but was never itself an intrinsically democratic institution. Representation traditionally operated on the basis of exclusion, and this has continued consequences for how parliament functions today in the context of contemporary representative democracy. In the British system, MPs have always acted as trustees rather than delegates, with clear implications for how the electorate exercises popular control over its representatives. Trusteeship is tempered by the understanding that if the electorate is unhappy with an MP, they can be ejected at the 
next election. However, the ancient basis for representative government is problematic in an era of representative democracy, as Judge explains:

The vagaries of the first-past-the-post electoral system and its ramifications for the 'strength' and 'responsiveness' of representative government, and the limited opportunities for public participation in decision making and hence the limited form of representative democracy itself, have been sufficient to prompt concern about a growing de-legitimation of representative processes in Britain. ${ }^{3}$

Of course, as Hirst observed, 'limited participation is an institutional feature of mass democracy and not merely a failing due to specific circumstances. ${ }^{4}$ Yet, the basis of the claim for an impending participation crisis is that people are choosing not to participate when they have the opportunity to do so, during elections. The ramifications for Westminster are clear: parliament is primarily an institution of representation, which has evolved to function in an era of mass democracy, but that functioning is called into question because of declining voter turnout. Parliament therefore faces a problem in terms of how its representative structures can be developed and adapted around the changing nature of British representative politics, and also complemented by more participatory mechanisms to provide additional opportunities for the public to contribute to political life.

In discussing parliament's response to political disengagement, its representative, rather than democratic, origins are of paramount importance. Also of crucial importance is the fact that parliament does not function as a 'unified' institution, and largely lacks any kind of corporate identity, and therefore also lacks the means to approach political disengagement in a holistic fashion. Despite this, parliament has tried to improve the health of its relationship with the public, and it has done so by way of investigations and reports emanating from within its committee structure. The House of Commons Modernisation Committee has examined this matter in some depth, publishing a report, Connecting Parliament with the Public, in 2004, with a follow-up inquiry conducted in 2006. The report acknowledged that the continued legitimacy of the House of Commons was dependent on it securing the engagement of the electorate, and that declining levels of political participation and trust in Britain were a threat to that legitimacy. The report 
examined five key aspects of parliament's relationship with the public: how it connects with young people; how it provides information to the public; how it facilitates access to the public; how it enables people to petition it; and how it interacts with the media. Other committees, such as the House of Commons Procedure Committee, have also placed the issue of public engagement with parliament relatively high on their agendas. Analysis of how these committees have dealt with the idea of political engagement in part illuminates parliament's approach to dealing with disengagement and, of particular interest, what this means for parliament's representative and democratic roles.

\section{Political Information and Political Communication}

Traditional ways of conducting political life tend to endure at Westminster, and this is particularly the case with respect to parliament's function in disseminating information about politics to the public. Through its debates, questions, and legislative and executive scrutiny, parliament produces a wealth of material that can keep the public informed about politics. Much of parliament's focus on connecting the public with its work is centred on enhancing the kinds of information that it makes available, and on improving public access to that information.

The most fruitful avenue of communicating with the public in recent years has been the internet, and this resource has been a particular focus for parliament. The parliamentary website has been subject to regular, incremental changes to make it easier to use and navigate, and the internet is viewed by most parliamentarians as a key resource inviting extensive exploitation. Through recent changes, the website has hosted a weekly newsletter, Commons Knowledge, which clearly and coherently outlines forthcoming parliamentary work and activities. Enhanced information dissemination about parliament's work is based on the theory that the more politically informed the public is, the more willing it is to engage with politics. Naturally, we should be cautious about the extent to which the internet can enhance political knowledge and, as a result, foster deeper engagement. The improvement of parliamentary information on the internet may make it easier for those who are already engaged in politics to find relevant facts and details, but may not necessarily encourage the un-engaged to seek out political information. Much also depends on the nature of the information provided. In the course of a series of interviews with the author in January and March 2006, one Labour Party 
peer explained that 'the public aren't interested in how the engine works, but what the car can do in terms of performance,' stressing that the emphasis should not be on how parliament works, but on what it actually achieves. From this perspective, improved information dissemination begins with better documentation of parliamentary output, but must also involve demonstrating the outcome of parliamentary debates and committee inquiries. Yet, in distinguishing between output and outcome, tricky party and partisan waters must be crossed, which is why parliament - and the House of Commons in particular - has always found this quite difficult. In the adversarial atmosphere that structures Westminster, describing the outcomes of parliamentary work, rightly or wrongly, involves the language of victory and defeat in the context of executivelegislative relations, and raises at least two problematic questions. First, who defines outcomes? Second, who speaks on behalf of parliament in describing those outcomes?

The Modernisation Committee veered away from these questions, and chose to focus instead on how enhanced information provision could be complemented by better twoway communication processes facilitated by the internet, aimed at developing a qualitatively new kind of dialogue between parliament and the public. As an interactive medium, the internet is valuable in providing public feedback to parliament about its work and activities, and therefore as a means of facilitating online consultation processes. The House of Commons has undertaken a number of consultation experiments in recent years, and parliamentarians have viewed this as a useful way of including those who would otherwise be excluded from political discussion and debate. Online consultations are endorsed as a useful parliamentary mechanism, but only on the grounds that their purpose is made clear to participants, who should understand their role is to provide advice and information, not to make policy. ${ }^{5}$ In emphasising that such consultations will remain within the parameters of traditional representative democracy, such language demonstrates that the trustee/delegate debate is alive and well in British politics.

The UK parliament has run a number of online consultations so far, with a dedicated website, TellParliament, emerging to host them. The Joint Committee on the Draft Communications Bill was the first to use an online consultation as part of its prelegislative scrutiny. The committee was enthusiastic about the impact these innovations had on the conduct of its inquiry, and on the openness of its deliberations. ${ }^{6}$ Select 
committees have also used online consultations as part of their inquiries. For example, in 2004, online consultation used during an investigation by the Science and Technology Committee into human reproductive technologies was viewed as providing 'a useful context against which to consider the formal evidence. ${ }^{7}$ The Northern Ireland Committee used online consultations during its work on hate crime, in the hope that this would widen the pool of people involved in the consultation process, given the delicacy of the issues involved, although the exercise did not attract a high number of participants. ${ }^{8}$ Low participation rates are problematic, because although these processes may succeed in including previously excluded groups or individuals, the costs of such consultations may be prohibitive if not offset by respectable participation rates.

Of particular consequence for how parliament and its members view their representational and democratic roles is how MPs themselves interact with these processes. The evidence suggests that what is taking place during online consultations is not 'real' interaction at all. For example, one parliamentary clerk concluded that, far from being 'a vibrant community of people discussing issues', online consultation forums had instead become 'a rather dry and dead succession of comments'. ${ }^{9}$ One inquiry run by the House of Commons Defence Committee in spring 2006, for example, listed 128 responses, but only 12 of these came from committee MPs. Of these, most were designed simply to prompt users for new information, rather than respond to and engage with the discussion. In this respect, while MPs may well have been reading the comments posted during the consultation process, it remains unclear that a deliberative dialogue was taking place between MPs and the participants. Nonetheless, $73 \%$ of online consultation participants surveyed have described the experience as positive, and one through which they learned from the other participants. ${ }^{10}$

These mechanisms are still in their infancy at Westminster, and there is much still to be learned, particularly in terms of ensuring that participants are clear about how their contributions affect parliamentary work, publications and recommendations. The present practice of online consultation confirms the continued centrality of parliament as a forum for traditional representational mechanisms, which naturally comes as no surprise. What remains unclear is the extent to which parliament actually wants to foster participatory processes that encourage an altogether new form of political involvement. For the moment, while online processes are a significant innovation, they assist mainly in 
helping the public convey views and information to MPs in the classic representative tradition, rather than foster the kinds of deliberative dialogue endorsed by some schools of democratic reform. Yet over time, online consultation can help underpin 'a more direct form of representation (in contradistinction to direct democracy) in which the public is less likely to feel unheard.'11

\section{Strategies of Connection}

Better use of the internet is a key part of parliament's attempt to connect the public with its work, but it has also utilised other strategies too, many of which continue in the vein of enhancing its representational credentials, and as an institution geared towards informing people about its work, rather than actively involving them in it. This is particularly true of parliament's developing approach to engaging young people, which is firmly located in the context of providing education about parliament as a necessary basis for better engagement and understanding. Work has focused on the Parliamentary Education Unit, which facilitates parliamentary visits, mock parliaments and outreach work, and on increasing the resources available for these activities. The Modernisation Committee has championed the use of new voters' guides to be sent to people as they approach voting age, in order to mark the occasion as significant and to provide information about the voting process. This strategy is underpinned by the idea that the more people know about parliament and how it works, the more likely they are to engage with it. As one Liberal Democrat peer explained to the author, there is a need to 'make youngsters aware that there is nothing that goes on in terms of legislation that does not affect their lives.' In the longer term, innovations such as the new voters' guide may contribute to the creation of a corporate identity of the kind that parliament has struggled to secure in the past.

Complementing an approach to educate young people is an approach to educate and inform the public more broadly by enhancing parliament's media strategy, which may also in turn help contribute to a parliamentary corporate identity. The idea of a parliamentary media strategy is a difficult one to grasp. The two separate Houses of Parliament have traditionally conducted media relations in their own different ways, which in itself crystallises the problems associated with talking about a 'parliamentary' strategy towards anything. Work conducted by extra-parliamentary organisations has pointed to the extent of the work required in this area. The Hansard Society Commission 
on the Communication of Parliamentary Democracy, for example, which reported in 2005, argued in its report, Members Only? Parliament in the Public Eye, that parliament was failing to engage with the opportunities provided by modern communications, and had therefore contributed to the alienation of the British public from political life.

Despite some increases in resources, parliament's media capacity is no match to that of government. The fragmentation of parliament as a democratic institution was highlighted by a Labour MP, who explained during an interview with the author that 'it's very difficult for people outside to understand that the Houses of Parliament are not the sum total of the political parties.' Another Labour MP echoed this sentiment, arguing that 'I think parliament as an institution separate from government ought to be able to reach people directly.' Parliament, as an institution bifurcated by party, by party government, and by the asymmetry between the two Houses, has struggled and will continue to struggle with the idea of a unified communication strategy. As Lord Puttnam, chairman of the aforementioned Hansard Society Commission, remarked in an evidence session with the Modernisation Committee in March 2006, 'the public do not know who speaks for parliament'. While parties and governments have clear leaders who speak for them, parliament does not. This has an impact on whether people feel they identify with parliament, and therefore also on the extent to which they see it making a contribution to the political system.

An additional difficulty is that parliamentary work is not only very complicated, but can sometimes also be rather colourless, rendering a stimulating engagement strategy even more hard to come by. In many respects, the key obstacle is working out what should be the purpose and message of parliamentary communication. For some politicians, the answer is to ensure that personality and issues are brought together when communicating parliamentary information. For some politicians, the present media and communications environment is rich with opportunities for parliament. One Liberal Democrat peer explained, for example, that the traditional media could, in effect, now be bypassed:

This could be the golden age if we use it right. I think we should challenge the media by producing good quality material, and making it interactive, [so] that the media themselves try to get their act together to do a better job. 
It is also absolutely crucial to appreciate the evolutionary and incremental nature of parliamentary change, and the way they cumulatively amount to 'real progress.' For example, the relaxation of the rules for filming inside the Palace of Westminster has enabled television news journalists to locate their reports in the Central Lobby when appropriate, thus increasing the public's exposure to the physical reality of parliament. In addition, the general impression, though not scientifically verified, is that select committee work has enjoyed greater exposure in the print and broadcast media in recent years, largely down to an increase in resources aimed at publicising select committee activity, with the public consequently having better access to information about the output and outcome of the scrutiny work that these committees perform.

\section{Issues of Accessibility}

The accessibility of parliament, in terms of visits from the public, has long been a source of criticism. Challenging the idea that people should be referred to as 'strangers' in their own parliament, for which their taxes pay, was long the first step along the road to a deep discussion about the merits of wholesale parliamentary reform. The practice of calling visitors 'strangers' has now passed, but most people do not visit parliament at all, and many who do come as tourists, rather than as concerned citizens. Change has taken a remarkably long time to come in this area. The creation of a visitor reception centre, along with helpful visitor assistants, will together provide a more friendly welcome to the public. However important such changes may be, they may not necessarily address the issue of disengagement in any significant way. One Labour peer explained to the author:

It's like saying, a lot of people are losing their limbs in road accidents, so let's make sure there's a supply of sticking plasters. I'm in favour of these proposals, but they won't make more than a trivial difference. How many people will want to come and look around a visitor centre?

Accessibility issues do not only involve physical accessibility. Public petitions are an important way for people to communicate with parliament as an institution about their grievances. However, despite the effort that may be expended in generating a public petition, it remains unclear that such effort is worthwhile: although parliament sends copies of public petitions to government, not all receive a reply, and of those that do, 
their impact, either on parliament or government, is doubtful. The operation of the public petitions system has been the focus of committee inquiry in the past, but, in recent years, it has become a prominent aspect of the parliamentary agenda. This is in part because of a reorientation towards issues of public engagement overall. However, it is also partly a response to the way in which petitioning works elsewhere in the UK, and is thus a demonstration of institutional learning and (some) procedural transfer in action. The Scottish Parliament at Holyrood has, from its inception, endeavoured to make public petitioning an integral part of its organisational make-up. There is a dedicated Public Petitions Committee, which accepts both paper and electronic submissions. Petitions may be referred to other parliamentary committees, may form the basis for parliamentary debate, and, because of the procedures of the Scottish Parliament, can ultimately lead to legislative change. The operation of the petitioning system at Holyrood has therefore become a focus of interest for those Westminster MPs who are anxious to improve the way that the public engages with and impacts on parliamentary work.

In its original recommendations in 2004 to improve the accessibility and utility of the petitioning system, the Modernisation Committee recommended that petitions should automatically be referred to the relevant Commons select committee, which would then decide whether to conduct an inquiry into the issues raised, or simply ask for a governmental response to the issues. The Procedure and Liaison Committees rejected this idea of formal referral in reports published in 2004, on the grounds that the notion of referral 'might imply that committees would be expected (at least by the petitioners) to take some action. ${ }^{12}$ As with the development of online consultation, the concern here is again to ensure that improved accessibility to parliament does not undermine its representational role. Once more, the balance between trustee and delegate theory is seen to be a fine one in British parliamentary practice.

The Procedure Committee published a report in May 2007 on the House of Commons public petition process and how it could be improved. ${ }^{13}$ Crucially, the Committee visited the Scottish Parliament in 2006 as part of that inquiry, and met members of Holyrood's Petitions Committee as part of the learning process. A key part of the inquiry involved making a determination on whether Westminster should establish a similar kind of system where the public can petition the institution of parliament directly. Yet, while acknowledging the successes of the Petitions Committee in the Scottish Parliament, the 
Procedure Committee decided against recommending such a system for Westminster, swayed no doubt by the weight of evidence against it from MPs themselves, and resolved to maintain the system of petitions being directed towards individual MPs, rather than towards parliament as a whole. Deepened public engagement with regards to public petitions is therefore in the context of preserving the representational link between the individuals and their MPs, rather than in the context of expanding the representational capacity of parliament as a holistic institution by enabling the public to petition parliament directly.

The Procedure Committee was also hesitant with regards to e-petitions, committing to the idea in principle only, and pledging further work in due course on the practicalities of such a system. Indeed, the controversy surrounding the No.10 Downing Street e-petitions site in February 2007, when an anti-road pricing petition received 1.8 million signatures and prompted debate over the merits of such an electronic tool, will encourage careful scrutiny of how such innovations should be applied at Westminster. However, it can easily be argued that if any political institution in Britain should have a significant and embedded e-petitioning structure, it should be the Westminster parliament, not No.10 Downing Street. It is parliament that is the representational bedrock in British politics, and to which public concerns and grievances should be addressed. If part of parliament's task is to reclaim its reputation as an arena in which significant and meaningful political debate and deliberation takes place, prompted by the public, then a well-designed epetitioning structure could be a crucial procedural innovation, and could dovetail nicely with the apparent public appetite for political communication of this sort. Crucially, however, any e-petitioning system that does emerge will likely be based on e-petitions being directed towards individual MPs, not towards the institution of parliament, which simply serves again to underline the difficulties inherent in demarcating the functional integrity of parliament as a whole with respect to its relationship with the public.

Furthermore, despite some of the criticisms made of the No.10 Downing Street epetitioning process, it has at least been predicated on a belief that petitioners should receive an email response from the Prime Minister about their petition. As the Conservative MP Bob Spink explained to the Procedure Committee enquiry in January 2007, petitions can help address political disengagement 'because it engages [the public] in politics, particularly if they get a response, and I think that is where the [present] 
system falls down.' From this perspective on engagement, the public need convincing that politicians are listening to their petitions and that their petition results in some kind of meaningful outcome. The Procedure Committee recommendation for speedier government responses to public petitions and for the creation of opportunities to debate petitions in Westminster Hall may together be of some use in this regard.

\section{Parliament and Political Engagement}

For many analysts and observers, the key issue in all of this is trust: trust that political institutions are actually working for the benefit of the public. Lord Puttnam, addressing the Modernisation Committee in March 2006, explained that 'there is not a sense out there of being adequately represented ... [and] the public do not believe that they are being adequately communicated with.' Much also depends on the detail of how parliament seeks to engage with the public as an institution. The public regularly view politicians as party members, as government members, as constituency MPs, but rarely as parliamentarians. As Conservative MP Andrew Lansley explained, again to the Modernisation Committee in March 2006, the public 'do not find a space for parliament.'

How that space is found for parliament is the vexing issue, which in turn opens up debate over the future of representative democracy in Britain, and the extent to which the remedy for declining political trust and engagement is a move towards more deliberative and/or participatory democracy. The Power Commission Inquiry into British democracy, published in 2006, argued that the health of the political system could only be improved by moving towards a more participatory style of politics, and by providing more opportunities for the public to become involved in decision making. From such a perspective, the cure for the ills of democracy is more democracy. The approach taken by parliament, by contrast, is that the cure is rather to strengthen and supplement existing structures of representative democracy. The proposals recently made and pursued by various House of Commons committees are all geared towards incrementally enhancing and enriching parliament's representative mechanics and improving the quality and quantity of connectivity and interactivity between parliament and people. Innovative, if tentative, measures have been adopted, notably in terms of online consultations, and more such measures will no doubt follow in the future. 
That parliament's focus is on changing the way it performs aspects of its representational roles should come as no surprise. Parliament's reluctance to adopt more radical, participatory mechanisms as a way to address disengagement is a simple reflection of the representational origins of the institution, and of the fact that its adaptation to the democratisation of the British state has been firmly couched in its representational structures. Consequently, parliament's response is not a sign of institutional weakness or unwillingness to act on this matter - far from it. It is easy to criticise parliament in terms of its reforming efforts. Grand plans are announced and complicated schemes unveiled by concerned public bodies, and when parliament does not fully adopt them, it is viewed as a failure, as weak, as insignificant. Yet to acknowledge change only when it happens in a 'revolutionary' way is to fundamentally miss the evolutionary character of parliament, and to miss the incremental accumulation of important changes over time.

Parliament struggles with its identity as a holistic institution, and this struggle impacts on the kinds of strategies that it adopts when approaching the issue of political engagement. It cannot adopt programmatic plans for extensive reform and simply implement them: the presence of party and government deep within its structural fabric makes this impossible and, ultimately, undesirable. Yet parliament is gradually working towards building an institutional identity for itself, consciously or otherwise, the lack of which is unquestionably at the heart of the whole issue of how parliament approaches the public and engages with it. What is not in question, however, is that the road along which such an institutional identity is to be built will certainly be far from an easy one.

In one sense, people are not disengaged from parliament, because they have never been engaged with it in the first place. Engagement happens through MPs and through parties, who, at the individual level, provide the mechanisms through which parliament can act as a forum linking government and governed. Those who pine for a lost golden age of public engagement with parliament pine for something that never existed. Parliament's present attempts to engage the public more thoroughly with its work mark a whole new chapter in its existence as an institution of representative democracy. The Westminster parliament is now, albeit hesitantly, trying to carve out a space for itself as a clear and coherent institution, a space which is very firmly based on its representational functions and which draws on its traditional role within the political system. Parliament amounts to more than a collection of MPs and parties: parliament is significantly more than the 
sum of its parts, and always has been. In attempting to establish exactly how it is greater than the sum of its parts in the context of twenty-first century British democracy, parliament is reshaping and refining its representational mechanisms, building new capacity in terms of public involvement in its work, and learning from best practice elsewhere. In its changing relationship with the public, parliament is neither drowning nor waving, but incrementally addressing the various angles and edges of the problem of political engagement. In the interests of developing and defending the future of British representative democracy, we can only hope that parliament's efforts in time amount to consistent, meaningful and valuable change. 


\footnotetext{
${ }^{1}$ For example, M. Harrop, 'An apathetic landslide: the British election of 2001', Government and Opposition, 2001, 295-313.

${ }^{2}$ D. Judge, The Parliamentary State, London, Sage, 1993.

${ }^{3}$ D. Judge, Representation: Theory and Practice in Britain, London, Routledge, 1999, p.179.

${ }^{4}$ P. Hirst, Representative Democracy and its Limits, London, Polity Press, 1999, p.4.

${ }^{5}$ HC 368, Connecting Parliament with the Public, Report from the Modernisation Committee, London, HMSO, 2004, para.56.

${ }^{6} \mathrm{HC}$ 876, Report from the Joint Committee on the Draft Communications Bill, London, HMSO, 2002.

${ }^{7}$ HC 7, Human Reproductive Technologies and the Law, London:, HMSO, 2004; HC 199, Annual Report 2004, London, HMSO, 2005; both from the Science and Technology select committee.

${ }^{8}$ HC 548, The Challenge of Diversity: Hate Crime in Northern Ireland, Report from the Northern Ireland Committee, London, HMSO, 2005.

${ }^{9}$ Hansard Society, TellParliament.net: Interim Evaluation Report, London, Hansard Society, 2006.

${ }^{10}$ Ibid, p. 15.

${ }^{11}$ S. Coleman, 'Connecting parliament to the public via the internet', Information, Communication and Society, 2004, p.1-22.

${ }^{12}$ HC 1248, Public Petitions, Report from the Procedure Committee, London, HMSO, 2004.

${ }^{13}$ HC 513, Public Petitions and Early Day Motions, Report from the Procedure Committee, London, HMSO, 2007.
} 